\title{
Edukasi Gizi dan Pemberian Bantuan Kepada Keluarga Balita Gizi Kurang Terdampak Covid-19 di Kelurahan Kedaung Kota Bandar Lampung
}

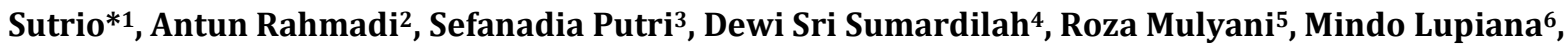 \\ Reni Indriyani ${ }^{7}$ \\ 1,2,3,4,5,6,7 Program Studi D3 Gizi, Politeknik Kesehatan Tanjung Karang, Indonesia \\ *e-mail: sutrio.syakir@yahoo.com ${ }^{1}$, nutrisicare@gmail.com² sefanadia@gmail.com $^{3}$, \\ iwed gizi@yahoo.co.id ${ }^{4}$, rozamulyani62@gmail.com ${ }^{5}$, mindo_lupiana@yahoo.com 6 , \\ reniindriyani@poltekkes-tjk.ac.id7
}

\begin{abstract}
Abstrak
Indonesia menghadapi tantangan yang kompleks masalah gizi dan kesehatan yang kemungkinan akan memburuk karena pandemi COVID-19. Hal ini berdampak pada kurangnya ketersedian pangan dan asupan makan terutama pada Keluarga terdampak covid-19 waktu singkat akan mengalami dampak berat dalam hal keamanan pangan rumah tangga dan keterbatasan terkait akses, ketersediaan, dan keterjangkauan bahan makanan sehat. Tujuan kegiatan pengabdian kepada masyarakat ini adalah meningkatkan kepedulian seluruh civitas akademika Poltekes Tanjungkarang dalam meningkatkan derajat kesehatan masyarakat, khususnya keluarga Balita Gizi Kurang Terdampak Covid di Kelurahan Kedaung. Kegiatan edukasi gizi dilakukan dengan metode konseling gizi dengan melakukan kunjugan rumah terhadap 12 keluarga balita gizi kurang. Hasil kegiatan pengabdian masyarakat ini adalah Keluarga balita sudah mengerti penyebab gizi kurang pada balitanya dan mampu mengatasi dengan pola asuh yang baik. Perlu pemantauan status gizi dan pendampingan gizi secara rutin oleh pihak puskesmas terutama bagi keluarga balita gizi kurang terdampak covid-19 oleh pihak puskesmas dan kelurahan kedaung.
\end{abstract}

Kata kunci: Gizi Kurang, Covid-19, Edukasi Gizi

\section{Abstract}

Indonesia faces complex nutritional and health challenges which are likely to worsen due to the COVID-19 pandemic. This has an impact on the lack of food availability and food intake, especially for families affected by Covid-19, a short time will experience a heavy impact in terms of household food security and limitations related to access, availability and affordability of healthy food ingredients. The purpose of this community service activity is to increase the awareness of the entire Tanjungkarang Poltekes academic community in improving the health status of the community, especially families of under-nutritionally affected children with Covid in Kedaung Village. Nutrition education activities were carried out using the nutritional counseling method by conducting home visits to 12 families of under-fives with malnutrition. The result of this community service activity is that toddlers' families have understood the causes of malnutrition in their toddlers and are able to cope with good parenting styles. It is necessary to monitor nutritional status and nutrition assistance regularly by the health center, especially for families of under-nutrition children who are affected by Covid-19 by the puskesmas and sub-district of Kedaung.

Keywords: Malnutrition, Covid-19, Nutrition Education

\section{PENDAHULUAN}

Indonesia sebelumnya merupakan contoh negara dengan "tiga beban malnutrisi”, jauh sebelum pandemi COVID-19. Masalah gizi utama di Indonesia masih didominansi oleh masalah Gizi Kurang Energi Protein (KEP), masalah Anemia Besi, masalah Gangguan Akibat Kekurangan Yodium (GAKY) dan masalah Kurang Vitamin A (KVA). Disamping itu diduga ada masalah gizi mikro lainnya seperti defisiensi zing yang sampai saat ini belum terungkapkan kerena adanya keterbatasan Iptek Gizi [1]. Indonesia memiliki 7 juta anak yang mengalami stunting. Kondisi ini menjadikan Indonesia sebagai negara kelima di dunia dengan balita stunting terbanyak. Lebih dari 2 juta anak merupakan balita kurus (berat badan yang tidak sebanding dengan tinggi badan) serta 2 juta anak lainnya mengalami kelebihan berat badan atau obesitas. Nyaris setengah dari total ibu hamil mengalami anemia karena makanan yang dikonsumsi tidak 
mengandung cukup vitamin dan mineral (zat gizi mikro) yang diperlukan [2]. Indonesia menghadapi tantangan yang kompleks akibat tiga beban tersebut yang kemungkinan akan memburuk karena pandemi COVID-19.

Anak dapat mengalami malnutrisi karena berbagai sebab. Tiga penyebab langsung malnutrisi paling umum, yaitu: (i) praktik menyusui yang tidak memadai dan pola makan yang buruk, ditambah praktik pengasuhan yang tidak optimal; (ii) nutrisi dan perawatan yang tidak memadai bagi ibu dan perempuan hamil; serta (iii) tingginya angka penyakit menular utamanya akibat lingkungan tempat tinggal yang tidak bersih dan tidak memadainya akses ke layanan kesehatan yang kurang memadai [3]. Faktor-faktor tersebut diperparah dengan kemiskinan yang luas, angka pengangguran, dan tingkat pendidikan yang rendah. Keluarga dan anak-anak yang jatuh miskin dalam waktu singkat akan mengalami dampak berat dalam hal keamanan pangan rumah tangga dan keterbatasan terkait akses, ketersediaan, dan keterjangkauan bahan makanan sehat.

Tingkat pendapatan keluarga dan pola makan salah satu pengaruh yang kuat terhadap status gizi anak. Setiap kenaikan pendapatan umumnya mempunyai dampak langsung terhadap status gizi, faktor yang paling menentukan kualitas makanan adalah pendapatan setiap keluarga. Pendapatan keluarga yang memadai akan menunjang tumbuh kembang balita karena orang tua dapat menyediakan semua kebutuhan anak baik primer maupun sekunder. Jika tingkat pendapatan naik, jumlah dan jenis makanan cenderung membaik pula. Namun, mutu makanan tidak selalu membaik jika tidak digunakan untuk membeli pangan atau bahan pangan berkualitas gizi tinggi [4]. Survei daring menunjukkan bahwa kebutuhan pangan semakin tidak aman, 36 persen dari responden menyatakan bahwa mereka "sering kali" mengurangi porsi makan karena masalah keuangan. Hilangnya pendapatan rumah tangga meningkatkan risiko anak mengalami kurus dan kekurangan zat gizi mikro. Gizi buruk merupakan salah satu bentuk kekurangan gizi yang membahayakan. Risiko kematian pada anak dengan kondisi tersebut nyaris 12 kali lipat lebih tinggi daripada risiko kematian pada anak dengan gizi baik. Anak-anak yang pulih dari gizi buruk mungkin akan terus mengalami masalah perkembangan dan pertumbuhan selama hidupnya [5]. Lebih jauh, berbagai upaya untuk menekan infeksi COVID-19 dapat mempersulit identifikasi dan pemberian perawatan serta layanan penting bagi anak-anak yang mengalami gizi buruk.

Pandemi ini berpotensi meningkatkan kekurangan gizi pada ibu khususnya anemia dan Kekurangan Energi Kronik. Akibatnya, kurangnya gizi pada ibu (terutama pada yang menyusui) dapat menimbulkan berbagai bentuk kekurangan gizi pada anak. Kemungkinan terganggunya layanan perbaikan gizi penting yang menyasar ibu hamil dan menyusui serta wanita usia subur (termasuk pemberian zat gizi mikro dan konseling pola makan) juga diperkirakan turut meningkatkan kekurangan gizi dan zat gizi mikro pada ibu. Jika berbagai upaya yang diperlukan tidak segera dilakukan, dampak jangka panjang akibat kurag gizi dapat meningkatkan jumlah balita stunting.

Kelurahan Kedaung merupakan salah satu wilayah kerja Puskesmas Beringin yang letaknya paling jauh diantara wilayah kerja lainnya dan masih banyak tempat yang sulit dijangkau sehingga rawan terhadap masalah kesehatan. Berdasarkan hasil pemantauan status gizi oleh Puskesmas di kelurahan Kedaung terdapat 12 balita gizi kurang yang dimungkinkan makin diperparah terdampak Covid-19 karena kurangnya ketersediaan pangan dalam keluarga.

\section{METODE}

Jenis kegiatan pengabdian kepada masyarakat yang akan dilakukan adalah edukasi gizi dengan metode konseling gizi dengan melakukan kunjugan rumah (Home Visite), yaitu keterlibatan sivitas akademika dalam mengaplikasikan keilmuannya sebagai konselor gizi. Sasaran kegiatan pengabdian kepada masyarakat ini adalah 12 keluarga balita gizi kurang terdampak covid-19 dengan melakukan home visite langsung dengan melibatkan kader posyandu. 


\section{HASIL DAN PEMBAHASAN}

\subsection{Perencanaan}

Lokasi Pengabdian Masyarakat dan Topik Pengabdian Masyarakat ditentukan berdasarkan surat tugas direktur nomor DP.02.01/I.2/1813/2020 tertanggal 18 Mei 2020 dan surat Puskesmas Beringin No. 440/94/V/2020 tertanggal 11 Mei 2020 perihal Permintaan Partisipasi Kegiatan Pemantauan Status Gizi. Kemudian Tim Pengabmas melakukan survey terlebih dahulu untuk mengidentifikasi permasalahan yang dialami oleh sasaran balita di Puskesmas Beringin dan Kelurahan Kedaung dengan menanyakan kepada Tenaga Pengelola Gizi Puskesmas Beringin Raya. Kegiatan dilanjutkan dengan kunjungan berikutnya untuk menyepakati topik dan waktu pelaksanaan. Berdasarkan kesepakatan tersebut selanjutnya tim melakukan rapat koordinasi untuk pembagian penugasan dan persiapan proses pelaksanaan.

\subsection{Pelaksanaan}

\subsubsection{Bentuk Kegiatan}

Kegiatan dilaksanakan di Kelurahan Kedaung dengan langsung mengunjungi Keluarga Balita Gizi Kurang Terdampak Covid-19. Kegiatan dilakukan dalam bentuk :

a. Menggali tentang permasalahan yang berdampak pada gizi kurang balita terdampak Covid-19

b. Konseling tentang Pola Asuh Kepada Balita meliputi :

1) ASI

2) Pemberian Makan

3) Pelayanan Kesehatan

c. Pemberian Bantuan Sembako

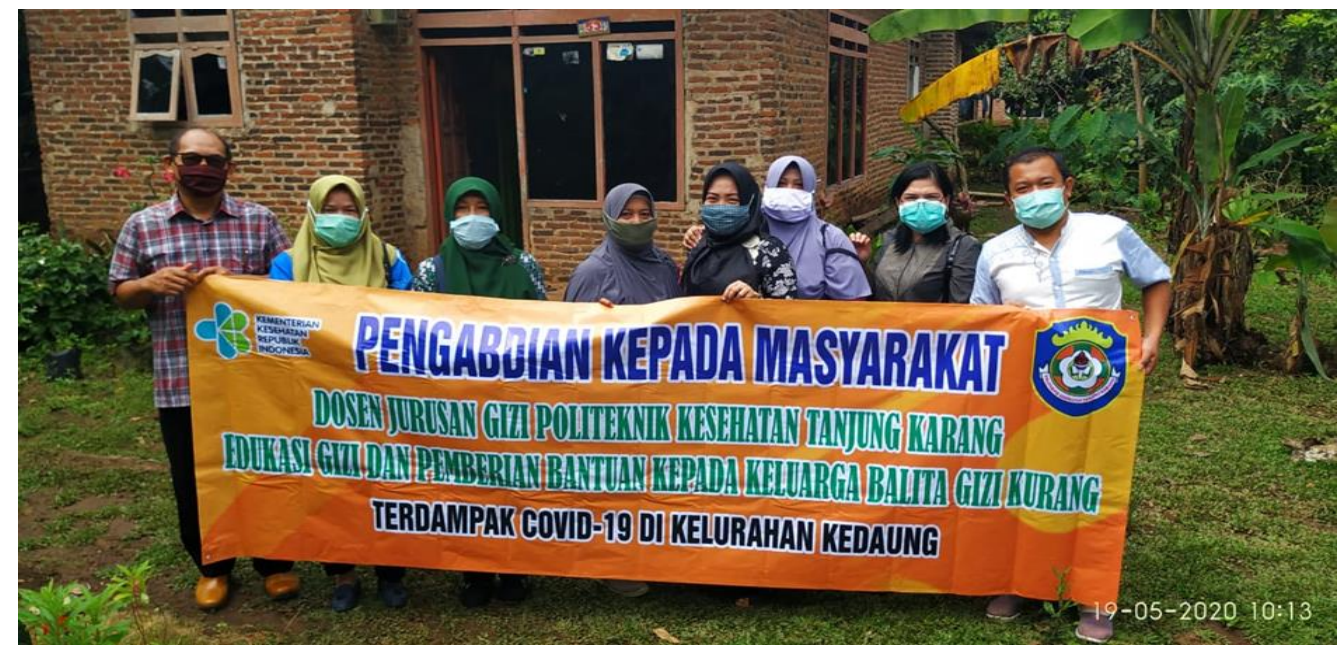

Gambar 1. Tim Pengabdian Kepada Masyarkat

\subsubsection{Sasaran}

Sasaran kegiatan ini adalah Keluarga Balita Gizi Kurang Terdampak Covid-19 berdasarkan informasi Puskesmas Beringin Raya dan Kelurahan Kedaung .

\subsubsection{Metode Pelaksanaan}

Metode yang digunakan dalam pelaksanaan edukasi gizi ini adalah konseling gizi, diskusi dan tanya jawab yang dirancang sedemikian rupa dan senyaman mungkin sehingga ibu balita gizi kurang memahami yang disampaikan oleh tim pengabmas. Aktivitas pelaksanaan kegiatan selain memberikan materi konseling gizi juga pemberian bantuan sembako kepada keluarga balita terdampak covid-19. 


\subsubsection{Waktu dan Tempat Kegiatan}

Kegiatan Pengabdian kepada Masyarakat ini dilakukan pada tanggal 19 Mei 2020 bertempat di Kelurahan Kedaung Wilayah Kerja Puskesmas Beringin Raya Kota Bandar Lampung.

\subsubsection{Sarana dan Alat yang digunakan}

Sarana dan alat yang dihunakan dalam penyampaian materi konseling dengan menggunakan Lembar Balik dan Leaflet.

\subsubsection{Hasil Kegiatan}

\section{A. Persiapan kegiatan}

Persiapan meliputi kegiatan rapat konsolidasi. Rapat konsolidasi membahas tentang lokasi kegiatan yang akan digunakan, jenis kegiatan pengabdian kepada masyarakat serta pembagian tugas dalam tim. Rapat koordinasi dilakukan dengan pihak Puskesmas Beringin Raya membahas tentang teknik pelaksanaan di lapangan dan bentuk kegiatan yang akan dilaksanakan.

\section{B. Koordinasi dengan mitra}

Mitra yang ditentukan sebagai lokasi adalah kelurahan Kedaung wilayah kerja Puskesmas Beringin Raya. Pemilihan lokasi adalah Kelurahan Kedaung merupakan salah satu wilayah kerja Puskesmas Beringin yang letaknya paling jauh diantara wilayah kerja lainnya dan masih banyak tempat yang sulit dijangkau sehingga rawan terhadap masalah kesehatan. Berdasarkan hasil pemantauan status gizi oleh Puskesmas di kelurahan Kedaung terdapat 12 balita gizi kurang yang dimungkinkan makin diperparah terdampak Covid-19 karena kurangnya ketersediaan pangan dalam keluarga.

Setelah melakukan koordinasi dengan puskesmas melalui kepala puskesmas dan kader posyandu telah disepakati bahwa pelaksanaan konseling gizi dapat dilakukan pada tanggal 19 Mei 2020 mulai pukul 09.00 sampai selesai. Sasaran penyuluhan adalah keluarga balita gizi kurang terdampak Covid-19. Pihak puskesmas dan kader posyandu membantu mendampingi tim pengabmas poltekkes Tanjung Karang.

\section{Pelaksanaan Kegiatan}

\section{a) Konseling Gizi}

Pada saat konseling diawali dengan menggali permasalahan perilaku makan pada anak dan menanyakan penyebab munculnya perilaku makan yang tidak baik.

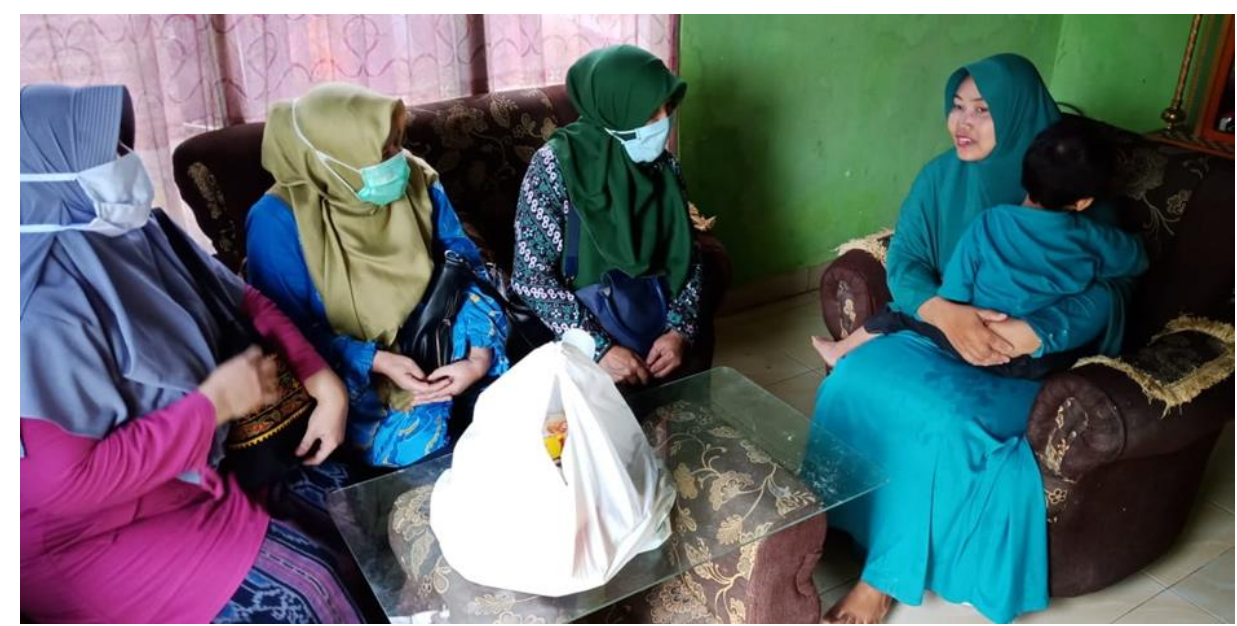

Gambar 2. Home Visite dan Konseling 
Hal tersebut dilakukan dengan mengajukan pertanyaan contohnya apakah anak mengkonsumsi sayur rutin dengan porsi yang cukup, mengapa tidak mengkonsumsi sayuran dan mencarikan solusi yang sesuai dengan kondisi anak dan riwayat pemberian Asi.

Adapun sebagai hasil kegiatan Edukasi Gizi ini, para ibu balita gizi kurang terdampak Covid-19 merespon dan memahami dengan baik dimana terjadi interaksi dua arah antara ibu dengan tim Pengabmas. Para ibu antusias dalam mengajukan pertanyaan seputar tetang gizi dan kesehatan berkaitan dengan pola asuh pemberian makan. Dan hasil rencana tindak lanjutnya adalah ibu akan memberikan pola asuh terbaik terutama dalam pemberian makan sehingga tidak berlanjut ke status gizi buruk. Untuk pengobatan penyakit yang diderita diarahkan untuk memanfaatkan fasilatas kesehatan masyarakat yang ada baik Puskesmas maupun puskesmas pembantu.

\section{b) Pemberian Bantuan Sembako}

Pemberian sembako merupakan bagian dari stimulasi bagi keluarga balita terdampak covid-19. Paket sembako yang diberikan berupa beras, minyak makan, telur, gula, tepung, mie instan, dan susu untuk balita. Dengan pemberian bantuan tersebut telah membantu keluarga balita gizi kurang untuk penyediaan makanan dalam keluarga.

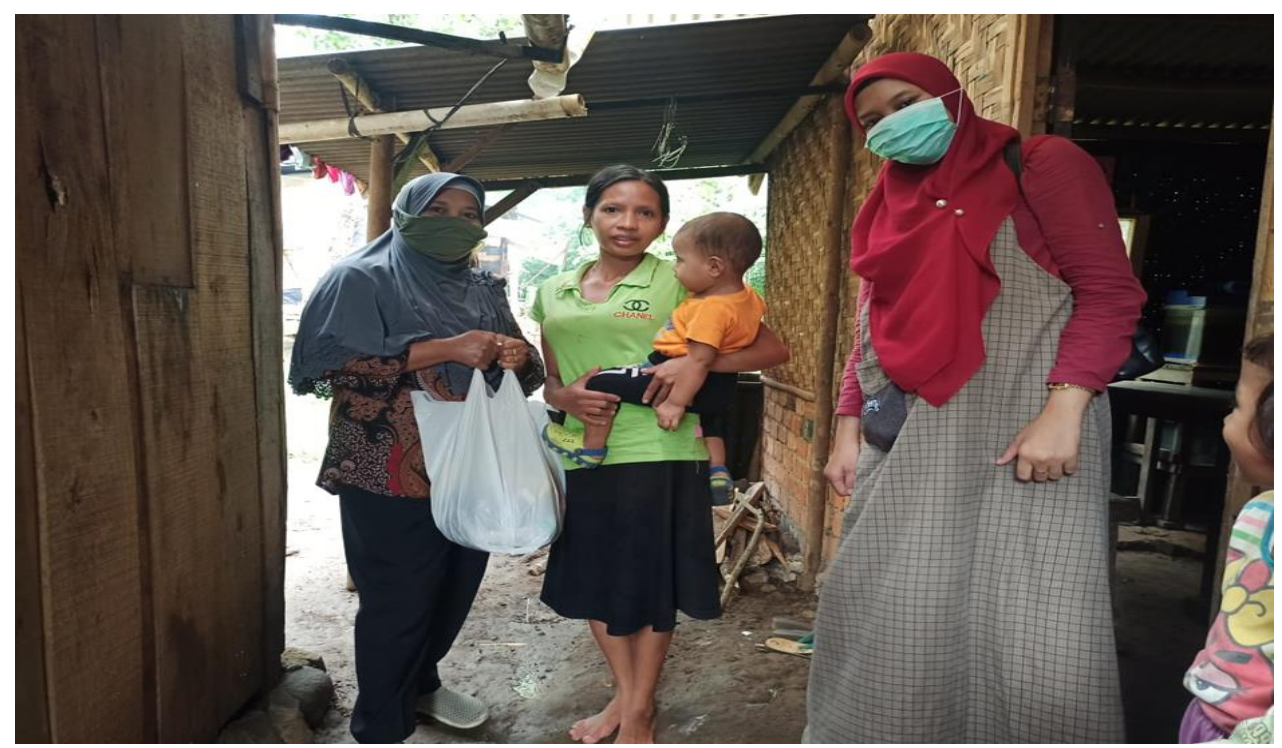

Gambar 3. Pemberian Bantuan Sembako

\section{KESIMPULAN}

Berdasarkan kegiatan yang dilakukan dapat disimpulkan bahwa keluarga balita gizi kurang terdampak Covid-19 sudah dapat mengerti dan memahami penyebab gizi kurang pada balitanya dan mampu mengatasi dengan pola asuh yang baik sesuai anjuran tim pengabdian kepada masyarakat dari Prodi D3 Gizi Poltekkes Tanjung Karang. Disarankan perlunya pemantauan status gizi dan pendampingan gizi secara rutin oleh pihak puskesmas terutama bagi keluarga balita gizi kurang terdampak covid-19 oleh pihak puskesmas dan kelurahan kedaung.

\section{UCAPAN TERIMA KASIH}

Penulis mengucapkan terima kasih kepada Jurusan Gizi Politeknik Kesehatan dan rekanrekan tim pengabmas secara swadana membantu kegiatan pengabdian kepada masyarakat. 


\section{DAFTAR PUSTAKA}

[1] I.D.N. Supariasa, "Penilaian Status Gizi (Edisi Revisi)," Jakarta. Penerbit : Buku Kedokteran EGC, 2013.

[2] Kementerian Kesehatan, "Riset Kesehatan Dasar (Riskesdas) 2018," Jakarta: Badan Penelitian dan Pengembangan Kesehatan Kementerian Kesehatan Republik Indonesia, 2018.

[3] UNICEF Indonesia, "Kajian Kapasitas Negara Memenuhi Kebutuhan Gizi," Jakarta, 2018.

[4] S. Mulyanto, "Sumber Pendapatan Pokok dan Penilaian Penyimpang," CV. Rajawali : Jakarta, 2010

[5] Hanna dan Olken, "Hasil Survei Daring Terkini”. 23 Black, Robert E., dkk., "Kekurangan Gizi pada Ibu dan Anak: Paparan global dan regional serta konsekuensinya terhadap kesehatan", The Lancet, 371, 9608, 19 Januari 2008, hal. 243-260 